\title{
About the Face and the expression. The Edenic time as revolutionary
}

Sobre o rosto e a expressão: O tempo edênico como revolucionário

\author{
Emmanuel Taub
}

\begin{abstract}
From the biblical text to the Jewish Philosophy of the Twentieth Century, from Walter Benjamin and Emmanuel Levinas to the philosophy of Martin Heidegger and Giorgio Agamben, from Rilke's poetry to the poetry of Paul Valéry, the problem of Face, expression and language have been a central topic of Jewish Thought. Among these problems, the discussion of sacred time and profane time becomes the place to think about the problem of Revelation. The main objective of this article is to analyze the Revelation from the perspective of Jewish Thought in relation to the language and problem of the divine Face. It will focus on this, by exploring the philosophy of Levinas and its connection with the biblical text, opening from there the reflection towards other authors in a friendly dialogue.
\end{abstract}

Keywords: Expression, Face, God, Levinas, Revelation

Resumo: Do texto bíblico à filosofia judaica do século XX, de Walter Benjamin e Emmanuel Levinas à filosofia de Martin Heidegger e Giorgio Agamben, da poesia de Rilke à poesia de Paul Valéry, o problema do rosto, expressão e linguagem tem sido um tema central do pensamento judaico. Entre esses problemas, a discussão do tempo sagrado e do tempo profano torna-se o lugar para pensar sobre o problema da Revelação. O objetivo principal deste artigo é analisar a Revelação a partir do pensamento judaico em relação à linguagem e ao problema do rosto divino. Concentrando-se nisso, o artigo explora a filosofia de Levinas e sua conexão com o texto bíblico, abrindo a partir daí a reflexão para outros autores em um diálogo amigável.

Palavras-Chave: Deus, Expressão, Levinas, Revelação, Rosto

"Good is Good and Evil is Evil.

Is this not the true definition of the revolutionary ideal?"

Emmanuel Levinas

"Wherever there is only the whisper of plants, a lament will be heard. Because nature is mute it becomes sad."

1 Consejo Nacional de Investigaciones Científicas y Técnicas, CONICET, Argentina <emmanueltaub@gmail.com> 


\section{Origin and revelation: biblical premises}

First premise:

God said, "Let the land produce living creatures according to their kinds: the livestock, the creatures that move along the ground, and the wild animals, each according to its kind." And it was so. God made the wild animals according to their kinds, the livestock according to their kinds, and all the creatures that move along the ground according to their kinds. And God saw that it was good. Then God said, "Let us make mankind in our image, in our likeness, so that they may rule over the fish in the sea and the birds in the sky, over the livestock and all the wild animals, and over all the creatures that move along the ground." So God created mankind in his own image, in the image of God he created them; male and female he created them. (Genesis 1:24-27 ${ }^{2}$ ).

Second premise:

"Then God blessed the seventh day and made it holy, because on it he rested from all the work of creating that he had done. [...] Then the LORD God formed a man from the dust of the ground and breathed into his nostrils the breath of life, and the man became a living being. [...] And the LORD God commanded the man, "You are free to eat from any tree in the garden; but you must not eat from the tree of the knowledge of good and evil, for when you eat from it you will certainly die." [...] Now the LORD God had formed out of the ground all the wild animals and all the birds in the sky. He brought them to the man to see what he would name them; and whatever the man called each living creature, that was its name. So, the man gave names to all the livestock, the birds in the sky and all the wild animals. (Genesis 2:3, 7, 16-17, 19-20).

Third premise:

"Then Moses said, "Now show me your glory.” And the LORD said, "I will cause all my goodness to pass in front of you, and I will proclaim my name, the LORD, in your presence. I will have mercy on whom I will have mercy,

\footnotetext{
${ }^{2}$ For Biblical quotes: Torat Emet (Bilingual edition), translate and edition Rabino Reuven Sigal, Buenos Aires, Editorial Keter Torá, 2007.
} 
and I will have compassion on whom I will have compassion." But, he said, "you cannot see my face, for no one may see me and live." Then the LORD said, "There is a place near me where you may stand on a rock. When my glory passes by, I will put you in a cleft in the rock and cover you with my hand until I have passed by. Then I will remove my hand and you will see my back; but my face must not be seen." (Exodus 33:18-23).

\title{
II. Face, revelation and language.
}

The Italian philosopher Giorgio Agamben, in his article published in 1984 with the title L'idea del linguaggio, tries to define and go deeper into the study of the idea of "revelation." As he suggests, nobody who has grown in a Jewish or Christian environment can be alien to this word. This way he will say that:

\begin{abstract}
The sense of the revelation is that man can reveal what exists through language, but he cannot reveal language itself. In other words, man sees the world through language, but he does not see the language. This invisibility of the revealing in that which he reveals is the word of God; it is the revelation. ${ }^{3}$
\end{abstract}

Rethinking the exposed by Agamben about the "revelation", and considering the previously defined premises, it could be said that God as revelation is found in man, however, man cannot see it. The face of God is revealed in man as a mark, remnant of an immemorial time. God is revealed to man and his face is concealed to dwell on his "aura." The expression -as mask of man's "aura"- covers the face that is forbidden. The expression is his language. This "creation in his own image" and this "breathing into his nostrils the breath of life" parallel to the forbidding of eating from the tree of the knowledge of good and evil, could be thought as the former movement to every ontology that Emmanuel Levinas studies throughout his work. A question that in the very bottom of its meaning imprints morals as legacy in man. Thus, God gives language by invisibilizing his face, while he reveals himself, because God is always "a 
unique and proper noun which does not fall within any grammatical category." 4

The expression of God is not found in his face, but consecrated in man's face. Man preserves the inheritance of his expression, of his work, that is our face. It is in man's face where ethical life is played because we have been consecrated to God's moral law. This is how Levinas explains that:

God is not simply the first other but other than the others [autre quautrui], otherwise, other with an alterity prior to the alterity of the other person, prior to the ethical compulsion to the neighbor. In this way God is different from every neighbor. And transcendent to the point of absence, to the point of his possible confusion with the noise of the thereis. 5

The naming word is given to man and from there he builds up his language. The power of naming rests upon God's inheritance to man. As God rests on the seventh day consecrating the Sabbath as sacred time, man starts his work right after his appearance on Earth.

God creates and orders the existence on Earth, names all and thus brings his creation to us. Any immemorial time that is preserved between the expression and the face is the divine time in which God's creation takes place, in which his work is "executed to be." But the time in the Garden of Eden is the time of the created existence: an inexpressible time for man. Time-in-the-state-of-revelation and time-in-pure-present. It is there where man names before God. Once God completes his work and consecrates the Sabbath (seventh day), man (an idle, without-work being), names (as could be seen in the passage of Genesis 2:19- 20) what is "presented" before him: what is existing in the world. God cannot name man's existence but through him. That is why, as Agamben states, revelation finds in its most proper sense the demonstration that "every word and every human knowledge is rooted in and founded on an opening that

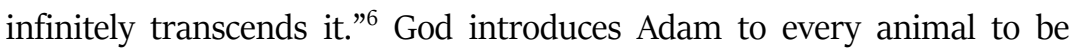

\footnotetext{
${ }^{4}$ LEVINAS (Emmanuel), De otro modo que ser o más allá de la esencia, tran. Antonio Pintor Ramos, Salamanca, Sígueme, 2003, p. 43.

${ }^{5}$ LEVINAS (Emmanuel), Dios, la muerte y el tiempo, tran. María Luisa Rodríguez Tapia, Madrid, Cátedra, 2005, p. 263.

${ }^{6}$ AGAMBEN (Giorgio), La potenza del pensiero. Saggi e conference, op. cit., 2005, p. 27.
} 
named. God is the existences' missing breath, the life "aura" that lies between the face and the expression.

In our days, in Agamben's view, we are standing on the limit of contemporary thinking. And this is how he continues explaining that:

If God was the name of language, "God is dead" can only mean that there is no longer a name for language. The fulfilled revelation of language is a word completely abandoned by God. And human beings are thrown into language without having a voice or a divine word to guarantee them a possibility of escaping from the infinite play of meaningful propositions. Thus, we finally find ourselves alone with our words; for the first time, we are truly alone with language, abandoned without any subsequent foundation. [...] The veils that theology, ontology and psychology cast over the human have now fallen away, and we can return them to their own place in language. We now look without veils upon language, which, having breathed out all divinity and all unsayability from itself, is now wholly revealed, absolutely in the beginning. Like a poet who finally sees the face of his muse, philosophy now stands face to face with language. ${ }^{7}$

Nevertheless, we should ask ourselves, what would be of an unveiled man, a man without a veil, without God's hand covering Moses to save him from death upon seeing his face? A face that is Glory, nature and revealed Name. God reveals his Name, and it is on his back that remains visible to Moses as he walks by, that rests the given language. The divine constitutes language's revelation itself and cannot be revealed. Language is divine language. The profaned word is a multiplied repetition from the revealed language uttered by man. Because naming something is at the very same time losing such thing. However, in this chance of naming God is found. That is why as Agamben explains in Il Regno e la Gloria: "The relationship between God and the world necessarily implies, however, an ontological problem, since it is not a relationship between two entities, but a relationship that concerns the eminent form from the same."

From another point of view, the revelation of the muse's face would be from its un-veiling the very end of the muse as imaginary for the poet. We must be cautious because in the attempt to unveil God's face, death awaits us. Upon language's alienation from divinity, an emptiness from

\footnotetext{
${ }^{7}$ AGAMBEN (G.), La potenza del pensiero. Saggi e conference, op. cit., pp. 33-34.

${ }^{8}$ AGAMBEN (Giorgio), Il Regno e la Gloria. Per una genealogia teologica dell'economia e del governo, Vicenza, Neri Pozza Editore, 2007, p. 100.
} 
which we might never be able to return awaits us. Being "alienated" is being thrown to a God-less language. A language that is emptied from divinity where there is no chance left but repeating old names. A language that names with words that vanish like the fog on the coast in a winter morning. A language that is closed to any creation -unrevealed-, induced by the unease for the loss of that which recalls us the sacred, like the feeling of knowing that we have a memory we cannot manage to bring back.

What have we lost? The chance to narrate our experience. As Walter Benjamin wrote in 1933, people fell silent when they returned from the battle fields. "Not richer in their communicable experience, but much poorer." Men had nothing left to tell the other the generations. And this way it becomes impossible to build the memory from the destruction of the experience.

It is this loss that is slowly taking from us that "aura" that made us men. The one that distinguishes us from the rest of the animal kingdom. This turn which leaves the past irrevocably buried is perhaps another of man's steps towards his transformation to the purest animality. Because the loss of sacredness in language is also the loss of the sacredness that remained in man's language, that is, the possibility to give names and the order that the name implies.

The problem of the contemporary man and of Modern Age is that from any possible angle of technology -specially from science- we attempt to disclose such immemorial origin on which revelation rests. Not only do we know and search for the "language names" but we also try to appropriate the Glory of God. The face of God, however, in its primary and unique- essence entails man's death. There is an impossibility of God's face towards man. Man is forbidden of seeing God face to face. It is his condition of incompleteness, the impossibility to see beyond the Other who presents himself as Highness, it is the limit of man before history. For such reason, the back is the limit from God to man, what is un-seen of man before himself.

The moral laws are the teachings that have been at first the legacy of Judaism on Earth. Particularly, the law that becomes the first instance on the ethical relationship towards otherness: "you shall not murder"; the 
revelation on the face that is opened to us. As Emmanuel Levinas explains, the act of seeing a face entails the hearing of "you shall not murder". It is in the sight of a face where we articulate "you shall not murder". Murder is only possible when the other's face has not been looked at. "The impossibility of killing is not real; it is moral. [...] the vision of the face is not an experience, but an exit from oneself [...] The moral view measures, in the face, the uncrossable infinity where the murdering intention ventures and fails." 10

The morality demand is reciprocity -as considered by Levinas-, a relationship between free people, as the equality among liberties. "What I am with respect to God, God is with respect to me." ${ }^{11}$ The dimension of the divine, says, stems from the man's face. It is the reciprocity with which I stand in front of the other, I achieve my own closeness to God, I shorten the rift, I open to a relationship with the other. That is why there cannot be "any 'knowledge' of God separate from the relationship with man", because "the Other is not God's incarnation, but it is precisely for his face, in which he is discarnate, the manifestation of the highness in which God reveals himself." ${ }^{12}$

But then, why is the face of God, in the first and final instances, the death of man? Why are we at the mercy of his look but forbidden from his face? Because God says to Moses that anyone who tries to look at him face to face will die, because his face -his Glory- is beyond man, is irresistible. There is a necessary sense of impossibility as non-possessing that which identifies him as man and that which is at the same time universal towards the rest of mankind. Moses sees God's back when he passed by, but he is placed in a cleft in the rock so that death does not reach him in the sight of God's face. If God is a moral relation prior to man, not killing another man is the very first and final premise of the standing-in-front-of-the other. But God himself (as the other's face) implies the death of all men. In any case, it is his back what is left to us, it is what God leaves in man. It is not a face, nor misery, nor the torn rags, but his back, the unfinished,

\footnotetext{
${ }^{10}$ LEVINAS (Emmanuel), Difícil libertad. Ensayos sobre el judaísmo, tran. Manuel Mauer, Buenos Aires, Lilmod, 2004, pp. 96-97.

${ }^{11}$ LEVINAS (E.), Difícil libertad. Ensayos sobre el judaísmo, op. cit., p. 302.

${ }^{12}$ LEVINAS (Emmanuel), Totalidad e Infinito. Ensayo sobre la exterioridad, tran. Daniel E. Guillot, Salamanca, Sígueme, 2006, p. 102.
} 
the somber as far as not seen, what exclaims us and requests us towards the other.

God is face-less because in his face man is left before death. That is why it could be said that God's face is impeded, unavailable before man's eyes. But it is in this un-availability that man's existence is possible. God's face is both the denial and confirmation of man, revelation and concealment. God conceals his face and in this negation, he accepts existence. He activates, somehow, man's-existence-on-Earth.

\section{Expression and animality}

The other is presented, according to Emmanuel Levinas' words, through the presence of the face. He makes his appearance in the exact place where the epiphany of the face calls me: "The afterlife where the face comes from signifies as remnant. The face is in the remnant of the absolutely expired Absence, totally past." 13 The face comes from "beyond the world", from the eternal, where time is irreversible, where the past is hidden.

The past time and past itself become unrecognizable and cannot be separated. Eternity is a path where the past fades, becomes blurred, but in this same movement the remnant where the face comes from is left behind. In the afterlife where the epiphany of the face takes place I find the third person. In the remnant is -implicitly- presented a being who has been there. This is how in the face, the third person who looks at me in the other's eyes is present, humanity is looking at me, and this humanity demands justice. ${ }^{14}$ The epiphany of the face testifies the presence of the other, of all humanity.

The face is claiming for justice, and if it does so it is because the other and I are not ontologically the same. The Being that is external, God, and presents himself through the face where his infinity rests, from where it comes from, is prior to man and to language. We are originally different and the other -in his face- claims me for the justice of our asymmetrical relationship.

\footnotetext{
${ }^{13}$ LEVINAS (Emmanuel), Humanismo del otro hombre, tran. Daniel Enrique Guillot, México, Siglo XXI, 2001, p. 74 .

${ }^{14}$ LEVINAS (E.), Totalidad e Infinito. Ensayo sobre la exterioridad, op. cit., p. 26.
} 
This is how we always finds ourselves before the other, in an uneven position. The relationship with the other is produced in an asymmetrical manner. The other, for Levinas, is presented to us through the height in which we end up positioned as victims or hostages against him, in which we are always indebted in terms of responsibility. Levinas explains that: "the access to the other is not originally in my interpellation with the other man, but in my responsibility towards him. Original ethical relationship." For such reason: "I am never free of obligations with respect to the other. [...] A gratuitous responsibility like that of a hostage and that even reaches the substitution for the other, with no demand of reciprocity." 15 This is what he calls "an ethical inequality." I am always subordinated to the other, in an original diachrony: the first person in accusative and not in nominative case. Between the other and Myself, what we find is the epiphany of the face, Revelation, and embedded, the impossibility of murdering.

It could be said then that it is in the face where the idea of expression is subsumed and alongside, the idea of the masks. Man is a mask of himself through which he interacts with the other who is present above him. His face is a hidden face behind the expressions that externalize his life as an in-society-being. In this asymmetrical relationship where I find the other who demands from me.

Regarding the use of the expression, Giorgio Agamben dedicates an essay to Max Kommerell, a Twentieth Century German critic, where he goes deeper into this subject. His analysis is centered, through the reading of the German critic, in the loss of the expression in the modern bourgeois man. ${ }^{16}$ Agamben states that we find ourselves in "a time that has lost its expressions" and that for such reason man is obsessed with them. For men, from whom all nature has been removed, the expression becomes destiny. And the more did the expressions lose their gracefulness under the action of unknown powers, the more did life become indecipherable. When the most simple and daily expressions became weird as puppet gesticulations, then humanity -whose own physical existence had become

\footnotetext{
${ }^{15}$ LEVINAS (Emmanuel), Fuera del sujeto, tran. Roberto Ranz Torrejón and Cristina Jarillot Rodal, Madrid, Caparrós Editores, 2002, pp. 58-59.

${ }^{16}$ Analysis that should be read together with an article that the Italian philosopher published in 1992 under the name "Notas sobre el gesto." Cf. AGAMBEN, (Giorgio), Medios sin fin, tran. Antonio Gimeno Cuspinera, Valencia, Pre-Textos, 2001.
} 
sacred in the same way as incomprehensible- was finally ready for the massacre. ${ }^{17}$

However, it is not the expressions that are lost, since the expression is such thing given by God's in-expression in every act in which God is expressed. As remnant of the Absent, the "afterlife" where the expression that dwells on the face comes from. Where God has left his mark, in the absence that is left after the expression. It could be said then, that modern man's expressions have been petrified and have become, thus, a mere mechanical repetition of himself. Modern man's expression is hurt and petrified for the loss of humanity and community. Because if to Agamben, "the expression is the only place of community, the only possible city" ${ }^{18}$, the actual fact is the de-humanization of man in the sense of his transformation towards animality: loss and de-subjectivation. A mechanized expression that shows the current state of de-humanization of man.

Now it is not only that man in a simply biological state or the terminally-ill person whose expression is that of a face which has lost its masks, as an animalized face. But the petrification of the expression has become in the loss of the masks where man finds himself as naked as before death. What is more, the animalized face means death itself. Death in the sense of a face which tries to capture the afterlife which dwells in it. The face of God which remains shut between the face and the expression. And when the mask falls, along with it falls the inheritance that made us sacred, and the transformation to the purest animality is exposed as the end of man's Age.

Now let me recall the fact that God reveals himself concealing his face. Martin Heidegger, in a seminar in the winter of 1942-1943 about "Parmenides and Heraclitus" stated that the first beginning is "in fact, the turning point." Taking his words, we could say then that God is the beginning of the beginning that is later concealed. That is why for God, revelation is the concealment of his face, because otherwise man would die before him. Any experience of un-concealment belongs to man. Man is God's un-concealment. As Heidegger mentions in his lecture: "The unconcealed is then experienced each time more exclusively in its

\footnotetext{
${ }^{17}$ AGAMEBN (G.), La potenza del pensiero. Saggi e conference, op. cit., p. 246.

${ }^{18}$ AGAMBEN (G.), "Notas sobre el gesto”, Medios sin fin, p. 79.
} 
relationship with man and from man, that is, in its nature as something found." ${ }^{19}$ However, it should be better said that this unconcealment has no character of something found, but rather of "something given." This is so because it is God who reveals himself, as written by Levinas, in the epiphany of the Other's face. Moreover, God gives man the experience of his unconcealment through the concealment of His face. Under the expression that covers the mask God -concealed- rests.

It is highly interesting in Heidegger's lesson, the explanation he gives on the relationship between man and animals. To sketch his analysis and critique over "the open", Heidegger takes and rereads, what Rainer Maria Rilke writes in his octave Duino Elegies. This way he will say that:

The metaphysics that serves as foundation of the nineteenth century biologism and of psychoanalysis, that is, the metaphysics of complete oblivion of the self, stems from the unconcealment of all laws of the self, where the ultimate consequence is an "uncanny" hominization of the "creature", that is, here, the animal, and a concomitant animalization of humankind. ${ }^{20}$

For Rilke -in Heidegger's critique on his poetic stance- "the open" is what goes through both man and animal, and through every entity. We should nevertheless ask ourselves whether the question is how alienated we -humankind- are from the earth and from individualism (hidden, in the shadows of this time) that sometimes not even recognize the other (impeding the epiphany of the face) but through the animal. Alienated from an earth that, as Agamben explains reading Heidegger, names what is shut within itself by essence before the world: "work, the open."

Hence, what Rilke really observes or somehow foresees is, precisely, a metaphor of concealment -closure of "the open"- which covers our time as a shadow. Recalling Levinas' article published in 1975, "The name of a dog, or natural rights", where he tells about his experience as Nazi's prisoner and the encounter with a dog that appeared in the work field. This dog, which they named Bobby, lived in some corner around the

\footnotetext{
${ }^{19}$ HEIDEGGER (Martin), Parménides, tran. Carlos Másmela, Madrid, Akal, 2005, p. 176.

${ }^{20}$ HEIDEGGER (M.), Parménides, op. cit., p. 196.

${ }^{21}$ AGAMBEN (Giorgio), Lo abierto. El hombre y el animal, tran. Antonio Gimeno Cuspinera, Valencia, Pre-Textos, Valencia, 2005, p. 93.
} 
field and showed up at the moments of grouping and returning from the journey, "skipping around and barking of joy." What is interesting from this account is that the dog recognized them, beyond the parenthesis where they found themselves, where for the rest of humanity they were nothing, or nearly-men. In their condition at the verge of animality, Bobby saw them as men. That is why Levinas says: "For him -it was undeniablewe were men." 22

Levinas brings back another verse from Exodus (11:7) which states: "But against any of the children of Israel shall not a dog move his tongue, against man or beast: that you may know how that the Lord does put a difference between the Egyptians and Israel.” That is, dogs will become mute before the light of freedom and the death of first-born children. Do dogs become mute of stupor or astonishment? "In the supreme hour of its instauration -without ethics and without logos-, the dog will be testimony of the person's dignity. That means to be the man's best friend. Transcendence in the animal!" 23

Nevertheless, this is not yet the key we are searching for, but rather the first turn to open the philosophical thinking. There is a face, exposed in the animality of the animal itself, of the most faithful friend -the dog-, which is opened to us, that is shown and revealed -that transcends- in which we attest our dignity as men. It is no longer God revealed in the opening of the Other's face, but now, it is pure nature -the most natural animality- that in its look, in its howlless silence attests us in our condition as men.

However, it is a fragile animality, because it is still pure animality. And that is why between the chien et loup, dog and wolf, under the dim light, where everything is blurry, one may not distinguish between the loyalty of the dog and the greed of the wolf, between the blurred undefined- dog that is still wolf, wishing the wrecked animal's blood spilt on the field.

Levinas discards continuing this line of thought to move forward on the Talmudic reading of the verse where the dog is "literarily a dog." And it is this line the one that the philosopher takes and where he finds

\footnotetext{
${ }^{22}$ LEVINAS (E.), Difícil libertad. Ensayos sobre el judaísmo, op. cit., p. 184.

${ }^{23}$ LEVINAS, (E.), Difícil Libertad. Ensayos sobre judaísmo, op. cit., pp. 218-219.
} 
the nodal statement to conceive of an exceptional space in his thinking, expressed through the delicate image of a "between parentheses."

Seventy prisoners -among whom he was included- go in a forestall commando in the Nazi Germany protected by French uniforms. Seventy Jewish men are transferred, who are however indefinite between existence and inexistence, since those people they come across with ("free men"), or whom they work for, do not deny them their look, but their faces instead. The humanity contained in them. And this way Levinas says:

They stripped us of our human skin. We were subhuman, a gang of apes. [...] But we were no longer part of the world. Our comings and goings, our sorrow and laughter, illnesses and distractions, the work of our hands and the anguish of our eyes, the letters we received from France and those accepted for our families - all that passed between parentheses. We were beings entrapped within the boundaries of their species; language-less beings despite all their vocabulary. ${ }^{24}$

The exception is built for Levinas in the impossibility of recognizing in the other a face, in those who look at them, as if they were not even animals (or dogs) and cannot see anything. This exception strips them off their "human skin", transforms them into "subhuman" to those who Levinas identifies as "monkeys", in a latent state, in a parenthesis. A situation between brackets that exceeds location, since it is in its extreme negativity a parenthesis in history: a parenthesis of "signifiers without signifieds" where language is devastated.

The exception is a reduction of man to the most animal limit of its species, to the blurred space between the man and the animal where language and the possibility of the look are removed. The exception is no only the situation of indistinction between fact and right, the founding sign of sovereign power in its containment of life and of the chance to act politically. The exception is, and for that Nazism is radical in both authors (and for modern thinking since the twentieth century), also a state of loss and withholding of life. A space, a "no place at all" that destroys the ontology governed by the chance of otherness as God's revelation; it is what we will call "blurred space." A blurred space is a space given to the indeterminacy and uncertainty. For example, the space between the face

${ }^{24}$ LEVINAS, (E.), Difícil Libertad. Ensayos sobre judaísmo, op. cit., p. 219. 
and the expression, where the outline of the face can be observed but the implications of the expression cannot be determined. This leads us to a situation of uncertainty generated by the blurred, vague, space, of beingand-not-being, which at the same time can cause fear of the other for not perceiving him as a close being in his consecration to me.

However, we have not finished discussing about Bobby and its importance in this history or theoretical reconstruction. Since Bobby was the dog who one day showed up in the field, "a homeless dog entered in our lives." The dog they called Bobby, survived in some corner around the field. He recognized them inside the parenthesis they lived in, where for the rest of humankind they were nothing, nearly-men, men at the verge of animality. For the dog, however, they were still men.

This conclusion that Levinas retakes opens a new line of understanding at the time of facing his reading about the limits of the face and what is hidden inside it and revealed. As he well explains throughout the Totalité et Infini, the other is presented as an opening through the face -it is the epiphany of the face- where I am finally invoked by the other's face who exclaims at me, where the Revelation was found, that is manifested as the pure justice and prior commandment to every ontology of the "shall not murder" (impossibility of murder), and a movement occurs inside this parenthesis. Within the limits of its own species man recognizes himself, finds the epiphany of the face, not in the other man but, instead, in a dog. Its imploring eyes, its perpetual invocation brings us back to the condition of men, fulfills us and, at the same time, confirms us that in that place we are not man for the other man.

Going back to what Heidegger criticized in Rilke, and putting it side by side with Levinas' account, it would be possible to suggest that within the boundaries of its own species where the epiphany of the face is inscrutable, man can recognize himself, not in front of the other man, but in a dog's pure animality. It is enlightening and connects us back to "the open.” And while in the condition of external I cannot be man (as in the case of a concentration camp) before the dog, in its animality, I keep and renew my re-cognition as such. Its face opens us up, unconceals us, drags us to "the essence of the truth."

As Paul Valéry has written about the human condition, the "man is only man thanks to a reduced number of men. But these need the rest to carry out and hold the unceasing labor of transformation, of no-repetition, 
that separates man from the no-man." ${ }^{25}$ And it is, perhaps, this relationship of transformation has been lost. That exercised the expression and reinforced the role of the mask as bond where to recognize the other. That which kept us as beings consecrated to God.

\section{L'Ineffable: sensitivity and opening}

In the face flooded of crying, tears could be "releases of the detaching being" ${ }^{26}$, in Emmanuel Levinas' words. A face that is exposed to the encounter with the other, the otherness of the neighbor, and where a "gap of no-place" unfolds enclosing the immemorial mystery in which the face is absent. Paul Valéry writes, in one of the most beautiful passages of his literature, such time-place that is the source where tears come from, immemorial mystery where the releases of the being sprout, L'Ineffable:

In the very bosom of the shadows where we fuse and confuse what belongs to our species and what belongs to our living matter, what belongs to our memories, and our hidden strengths and weaknesses, and what is, all in all, the unshaped feeling of not having always been and of having to cease being; is found that which I have called the source of tears: l'Ineffable. Because our tears, as I see them, are the expression of our impotence of expressing, that is, of releasing through the word the oppression of what we are. ${ }^{27}$

L'Ineffable, source of tears, is the immemorial place, "beyond the world", where God has revealed himself in the face of man. The tear comes from an immemorial time, a place that is not found in the own body -that is born from the purity of the being- and shutters it in its appearance in the present time. The path of the tear is drawn from that "afterlife" and is manifested in the time where we are standing-on-Earth. It is possible then, to understand this way Valéry's verses in his masterpiece The young Fate:

In the horror cave, within myself excavated, mutely gives off the water its mysterious salt.

\footnotetext{
${ }^{25}$ VALÉRY, (Paul), Los principios de an-arquía pura y aplicada, tran. Féliz de Azúa, Barcelona, Tusquets, 1987, p. 37.

${ }^{26}$ LEVINAS (E.), Humanismo del otro hombre, op. cit., pp. 13-14.

${ }^{27}$ VALÉRY (Paul), Diálogo del Árbol, tran. Rodolfo Alonso, Córdoba, Ediciones del Copista, 2004, p. 45.
} 
Where do you come from, tear? What is your spring?

What so new and sad work, eternally

from my bitter shadow is slowly oppressing you?

Of mother and of mortal my stairs you go climbing,

Oh stubborn burden! tearing and breaking

your way in my time. ${ }^{28}$

What is this time on Earth like? What is the immemorial time like? The time on Earth is, according to Valéry, monotonous, it is a time in constant-past or in constant future. Valéry suggests, in his The crisis of the Mind, that there is a human inversion of time where the man has its main seat in the past or in the future, and that is why:

He never remains in the present, unless constrained by the sensation: pleasure and pain. It could be said that he is indefinitely missing what is nonexistent. This condition is not animal, it is completely artificial, since all in all, is not strictly necessary to the being. ${ }^{29}$

This not being in the present works in the same way as the Captain Hagberd's "for tomorrow" that Joseph Conrad builds in his narration "Tomorrow." The "for tomorrow" ${ }^{\circ}$ is the expression of hopelessness of someone who has nothing left but is still alive: dejection. That which is desired and gets confused in time as an interrogation and for which waiting is not worth any longer, and however, it is waited for. The "for tomorrow" is to let yourself go. Something that never arrives, but still the chance to go on living. In the "tomorrow" there is no "today." It is the expression of a time without present. And there is no contemporaneity in such movement. There is only the "what is to come" or the past memory, a repeating endless en the vacuum.

In this life we find ourselves, in the modern man's, to live, for Valéry, is "an essentially monotonous practice." It is only through the "sensitivity" -the French thinker will say-that is possible to break, through intense shaking, the "deep monotony in the functions in life." ${ }^{11}$ Is it,

\footnotetext{
${ }^{28}$ VALÉRY (Paul), Poemas, tran. Carlos R. de Dampierre, Madrid, Visor, 1996, p. 57.

${ }^{29}$ VALÉRY (Paul), Política del espíritu, tran. Ángel J. Battistessa, Buenos Aires, Losada, 1997, p. 86.

$3^{30}$ CONRAD (Joseph), “Mañana”, Amy Foster y otros relatos, tran. Hernán Valencia, Goelkel, Buenos Aires, Punto de Lectura, 2007, p. 154.

${ }^{31}$ VALÉRY (P.), Política del espíritu, op. cit., p. 86.
} 
perhaps, because of the incompleteness of what we have been stripped off, of which we are missing and for which we "are here" -always in the state of permanent loss- that we do not manage to stand on the present but through pain and pleasure, through sensitivity?

As well analyzed by Agamben, man is idle by nature, since his life is "idle and purposeless", and it is through this lack of objectives that the incomparable effectiveness of the human species is possible. "Man has devoted himself to work and production for he is in his essence deprived of work, because he is a sabbatical animal by excellence." ${ }^{22}$ That is why he needs to get mudded in the routine to survive his nature. To get out of himself and become productive. And this is the routine that constitutes the monotony that Valéry refers to and where only through sensitivity it is possible for us to be uprooted. A sensitivity that is fading in the spirit of our time:

We moderns are not very sensitive. Modern man has blunted his senses; he puts up with every kind of noise, as we all know; he puts up with nauseating smells, with violently contrasting or insanely intense lighting; he is subjected to perpetual vibration, he feels the need of brutal stimulants, strident sounds, the strongest drinks, brief and bestial emotions. ${ }^{33}$

Walter Benjamin has written that we should think of Paul Valéry as a "great compass", who sinks one of his legs in the bottom of the sea while the other looks at the horizon and tries to reach it. And if there is a character in his literature who most precisely encapsulates his searches, it is Monsieur Teste. This unfinished and under-constant-production character (different tales and passages constitute, together with drafts and notes, the totality of the writings about Monsieur Teste) has become throughout his life the embodiment of the intellect. "Monsieur Teste is nothing but the individual who, being finally prepared to go through the

\footnotetext{
${ }^{32}$ AGAMBEN (G.), Il Regno e la Gloria. Per una genealogia teologica dell'economia e del governo, op. cit., p. 269.

${ }^{33}$ VALÉRY (P.), Política del espíritu, pp. 104-105.
} 
threshold of historical extinction, replies the call once again (like a shadow) and plunges into it immediately." ${ }^{34}$

In his "Letter from a friend", Valéry writes:

I think that every mortal contains right near the center of his machine, and in a privileged place within the instruments to navigate his life, a little mechanism of an incredible sensitivity that indicates the state of his selflove. It tells whether one admires oneself, adores, hates or crosses oneself out of the existence; and some living indicator quivering on the hidden quadrant vacillates terribly quickly between the cero of being a beast and the maximum of being a god. ${ }^{35}$

While he spends his life wondering about "the afterlife", immemorial time where revelation -his face- comes from, Monsieur Teste builds up his existence intellectually. And for that reason, he has tried to remain the most possible consecrated to the present: the only way to interrogate the being. That is why he will say that "sensitivity is everything, bears everything, evaluates everything" ${ }^{36}$. To consecrate oneself to sensitivity, that is what Teste ultimately devotes his life to, is to dwell on an eternal present. This is the reason why Valéry cannot kill or make Teste disappear, and his life is repeated and transcends beyond the author. This consecration to sensitivity, however, is only possible in Teste because he does not belong to this world. Instead, he is a being in the limit of the threshold of existence.

As we have seen in the Biblical premises, man is not born from the animal neither as any other animal. God creates him last and gives him control over the animal realm. But we must remember, however, that in the Garden of Eden the serpent also has the word (Genesis 3). It is the loss of the Paradise, the original sin, the exclusion of the animal from the kingdom of language.

The "afterlife", such immemorial time that leaves its mark in the face as God's revelation where language comes from, is the time in the Garden of Eden: the Edenic time. Adam gives names, nominates the

\footnotetext{
${ }^{34}$ BENJAMIN (Walter), "Paul Valéry. Con ocasión de su sexagésimo aniversario", Obras. Libro II / Vol. 1, op. cit., p. 408. Similarly, Agamben writes that Monsieur Teste is one of the "cornerstones of modern antihumanism.” Cf. AGAMBEN (G.), Lo abierto. El hombre y el animal, op. cit.
}

35VALÉRY (Paul), Monsieur Teste, tran. José Luis Arántegui, Madrid, Visor, 1999, p. 51.

${ }^{36}$ VALÉRY (Paul), Monsieur Teste, op. cit., p. 51. 
animals, the birds in the sky and the beasts (Genesis 2:19-20). But once the "Tree of the knowledge of good and evil" is corrupted, man becomes aware of his nakedness and enters the world of language and ethics. Good is good and evil is evil. There the historical time becomes the rupture of the Edenic time. Not only does he recognize his naked body in the other's, but also his nudity before the world he must inhabit: his weakness as man. This "sabbatical animal", as Agamben calls the nature of man, was the one who inhabited the Garden of Eden in an immemorial and divine time. A pure-present where, as Valéry also seems to suggest, we were closer to animality than what we think.

The Edenic time is a time in pure-present, a daily time, where there is no past, because Adam has no past, and in the same way there is no sense of future. For that, this time is a lost time that is impossible to return to. There, man is consecrated to his inoperative nature. The loss and expulsion from Paradise was the uprooting of present time. The corruption of the tree of knowledge faced man with the possibility of a finite existence. It turned him into a historical being. To find a time to come is the work we have left, a revolutionary time where the heightness of ethics is consecrated. For that reason, from the instant when man has come out of history, he has lived between the past and the future, where only through the sensitivity -wordless language- it is possible to invoke an immemorial time to gain the lost present. Pleasure and pain, as desecrated ways of clinging to the present, is what remains for this man who has become a being-in-history. And sensitivity, the tears plowing through the face, l'ineffable, is the reminiscence of the Edenic time. Only the messianic time will be the return to this revolutionary time of ethics: an inoperative pure-present where the fragility of the sabbatical animal coated by his nudity becomes nonexistent, returning to be of his very own nature.

\section{References}

AGAMBEN, (Giorgio), Medios sin fin, tran. Antonio Gimeno Cuspinera, Valencia, PreTextos, 2001.

AGAMBEN (Giorgio), Lo abierto. El hombre y el animal, tran. Antonio Gimeno Cuspinera, Valencia, Pre-Textos, Valencia, 2005.

AGAMBEN (Giorgio). La potenza del pensiero. Saggi e conference, Vicenza, Neri Pozza Editore, 2005. 
E. Taub - About the Face and the expression. | 71

AGAMBEN (Giorgio), Il Regno e la Gloria. Per una genealogia teologica dell'economia e del governo, Vicenza, Neri Pozza Editore, 2007.

BENJAMIN (Walter), "Experiencia y pobreza”, in Obras. Libro II / Vol. 1, Spanish Edition from Juan Barja, Félix Duque and Fernando Guerrero, Madrid, Abada, 2007.

CONRAD (Joseph), “Mañana”, Amy Foster y otros relatos, tran. Hernán Valencia, Goelkel, Buenos Aires, Punto de Lectura, 2007.

HEIDEGGER (Martin), Parménides, tran. Carlos Másmela, Madrid, Akal, 2005, p. 176.

LEVINAS (Emmanuel), De otro modo que ser o más allá de la esencia, tran. Antonio Pintor Ramos, Salamanca, Sígueme, 2003.

LEVINAS (Emmanuel), Difícil libertad. Ensayos sobre el judaísmo, tran. Manuel Mauer, Buenos Aires, Lilmod, 2004.

LEVINAS (Emmanuel), Dios, la muerte y el tiempo, tran. María Luisa Rodríguez Tapia, Madrid, Cátedra, 2005.

LEVINAS (Emmanuel), Humanismo del otro hombre, tran. Daniel Enrique Guillot, México, Siglo XXI, 2001.

LEVINAS (Emmanuel), Fuera del sujeto, tran. Roberto Ranz Torrejón and Cristina Jarillot Rodal, Madrid, Caparrós Editores, 2002.

LEVINAS (Emmanuel), Totalidad e Infinito. Ensayo sobre la exterioridad, tran. Daniel E. Guillot, Salamanca, Sígueme, 2006.

Torat Emet (Bilingual edition), translated and edited Rabino Reuven Sigal, Buenos Aires, Editorial Keter Torá, 2007.

VALÉRY (Paul), Diálogo del Árbol, tran. Rodolfo Alonso, Córdoba, Ediciones del Copista, 2004 .

VALÉRY (Paul), Monsieur Teste, tran. José Luis Arántegui, Madrid, Visor, 1999.

VALÉRY (Paul), Poemas, tran. Carlos R. de Dampierre, Madrid, Visor, 1996.

VALÉRY (Paul), Política del espíritu, tran. Ángel J. Battistessa, Buenos Aires, Losada, 1997.

VALÉRY, (Paul), Los principios de an-arquía pura y aplicada, tran. Féliz de Azúa, Barcelona, Tusquets, 1987.

Data de recebimento: 11/01/2018

Data de aceite: 10/03/2018 